\title{
Peer influences on college drinking: A review of the research
}

\author{
Brian Borsari*, Kate B. Carey \\ Center for Health and Behavior, Syracuse University, 430 Huntington Hall, Syracuse, NY 13244-2340, USA
}

\begin{abstract}
Peer pressure is consistently implicated in the excessive drinking of college students. However, both theory and empirical findings suggest that peer pressure is a combination of three distinct influences: overt offers of alcohol, modeling, and social norms. Overt offers of alcohol can range from polite gestures to intense goading or commands to drink. Modeling occurs when the student's behavior corresponds to another student's concurrent drinking behavior. Perceived social norms can serve to make excessive alcohol use appear common and acceptable to the student. This review critically examines the literature on each form of peer influence and provides suggestions for future research. (C) 2001 Elsevier Science Inc. All rights reserved.
\end{abstract}

Keywords: College drinking; Peer influence; Active influence; Drinking norms; Modeling

\section{Introduction}

The initiation (Lo \& Globetti, 1993) or increase (Baer, Kivlahan, \& Marlatt, 1995; Leibsohn, 1994) of alcohol use often occurs during the college years. Individuals entering college show marked increases in alcohol and drug use, compared to those that live at home or get jobs following graduation from high school (Johnston, O'Malley, \& Bachman, 2000). Peers are consistently associated with such alcohol use, and although the term "peer pressure" receives a great deal of attention, precise definitions of it are rare. Phrases like "pressure to conform" and the attraction of "being part of a group identity" are often used to describe what makes peer influence so potent (Greenspan, 1998, p. 104). However, such

* Corresponding author. Tel.: +1-315-443-3597.

E-mail address: beborsar@psych.syr.edu (B. Borsari). 
definitions are vague and perpetuate the perception of peer pressure as a one-dimensional influence on behavior. In reality, peers influence the individual's attitudes and behaviors in several ways. This paper details the reasons on why college drinking is strongly influenced by peers and reviews the empirical literature to demonstrate the multiple pathways by which peers can influence drinking behavior.

\subsection{Influence of peers in college}

Two aspects of college life make it an ideal environment in which to study peer influence on alcohol use. First, there is a pronounced shift in influence from parents to peers during college. Both peers and family influence alcohol use over the child's course of development (White, Bates, \& Johnson, 1991). Early on, parents have a strong influence on the child's attitudes and behaviors (Kandel \& Andrews, 1987). As adolescents get older, they spend less time with their parents and more time with friends (Csikszentmihalyi \& Larson, 1984), resisting the attempts of parents to control the selection and association of these friends (Smetana \& Asquith, 1994). Peers become increasingly important and are relatively independent of parental oversight or control (Brown, Dolcini, \& Leventhal, 1997). This process intensifies in college. Matriculating students seek to establish a peer network that can be a source of support and intimacy (Paul \& Kelleher, 1995), and assist the transition to college by providing role models and social opportunities (Hays \& Oxley, 1986). Using alcohol frequently facilitates the adoption of a new college student identity as well as serving as markers of freedom from parental control (Maggs, 1997).

Second, the prevalence of alcohol-based social opportunities on campus contributes to the potency of peer influence on individual attitudes and behaviors. Alcohol is a prominent part of the college culture, present at most social functions and part of many peer interactions (Thombs, 1999). Most students begin drinking alcohol by the time they arrive at college (Johnston et al., 2000) and many view college as a place to drink excessively, in a timelimited fashion, before assuming the responsibilities of adulthood. Because peers are the most salient social referents in the college environment (Perkins, 1997), they are a potent influence on alcohol use. Most new acquaintances at college will be drinkers: recent research indicating that four out of five college students drink (Wechsler, Lee, Kuo, \& Lee, 2000). In addition, college peers tend to be more approving of alcohol use (Johnson, 1989).

In sum, peers play a considerable role in the development and maintenance of alcohol use in college students. To develop a peer network on campus, students immerse themselves in the social environment (Martin \& Hoffman, 1993). The prevalence of alcohol use on campus makes it likely that students will encounter peer-drinking levels and alcohol-related attitudes unlike anything encountered before (Schulenberg, Bachman, O’Malley, \& Johnston, 1994). Exposure to such drinking often leads to increased alcohol use: students residing in places where "heavy drinking is approved and where alcoholic beverages and the places to consume them are readily available will drink relatively heavy on the average" (Schall, Kemeny, \& Maltzman, 1992, p. 134). Thus, alcohol-related attitudes and behaviors of peers are consistently related to personal attitudes and behaviors (Brennan, Walfish, \& AuBuchon, 1986). 


\subsection{Overview of review}

The purpose of the literature review was two-fold. First, we critically review the literature on peer influences on drinking. Peer influences are those interpersonal factors present in the immediate or potential drinking environment. Social-cognitive theory suggests that peers can exert their influence on alcohol use by actively shaping drinking behavior, or through more cognitively based social influence processes (Maisto, Carey, \& Bradizza, 1999). The peer influences reviewed here include: (a) active offers of alcohol, (b) modeling of others' drinking, and (c) perceived drinking norms. Second, using the current state of the literature as a guide, we provide recommendations for future research on peer influences.

The following criteria guided decisions regarding the inclusion of studies in the review. First, studies were included if they discussed the influence of platonic peers, friends, best friends, or fellow students on drinking. Second, only research published after 1970 was cited. This decision was merited by the increase in the interest, quality, and funding of alcohol research during the 1970s (Leonard \& Blane, 1987). Although valuable research on college drinking had been performed earlier (e.g., Straus \& Bacon, 1953), its exclusion does not detract from the conclusions of the present review. Third, studies were excluded if there were major design flaws, unclear operationalization of dependent or independent variables, or inappropriate statistical analyses performed. Fourth, conference presentations and unpublished manuscripts were not included because they had not received peer review. Finally, only studies performed with Canadian and American college students were included due to the similar role alcohol plays in socialization at Canadian and American colleges (Maggs, 1997).

\section{Peer influence: literature review}

The organization of the literature review follows a framework developed by Denise Kandel (1985). Consistent with the principles of social learning theory, this framework posits that peers influence alcohol use in two ways: directly and indirectly. Direct (or active) peer influences explicitly focus on getting a person to drink, and can range from polite gestures (e.g., offering to get a peer a drink, buying a round) to overt commands or encouragement to drink (e.g., forcing others to drink during drinking games). However, peer influences on drinking behaviors are not limited to direct offers or urging to drink. Peers, through their own actions, may provide information about what behaviors are accepted and admired, what is considered appropriate in a given social context, and therefore what behaviors are likely to lead to social acceptance and reinforcement. Modeling and perceived norms are two indirect (or passive) influences that have been linked to drinking behavior. Each of these indirect influences set the stage for anticipated social reinforcement.

\subsection{Direct peer influence}

The research in Table 1 indicates that while direct offers to drink are associated with alcohol use and problems (Wood, Read, Palfai, \& Stevenson, 2001), studies examining this 
Table 1

Direct influences literature

\begin{tabular}{|c|c|c|c|c|}
\hline Authors & Subjects & Design & Results & Limitations \\
\hline \multicolumn{5}{|l|}{ Qualitative } \\
\hline $\begin{array}{l}\text { Rabow and } \\
\text { Duncan-Schill } \\
\text { (1994) }\end{array}$ & $76 \mathrm{M} / \mathrm{F}$ & $\begin{array}{l}\text { Participants kept drinking } \\
\text { diaries for } 28 \text { days }\end{array}$ & $\begin{array}{l}\text { - Drinking is common at social } \\
\text { functions, and being without a drink } \\
\text { invites comments and offers of alcohol. } \\
\text { - Active influence especially } \\
\text { prevalent at Greek system functions. } \\
\text { - Alcohol prevalent at residence hall } \\
\text { parties, as well as repeated drink offers. } \\
\text { - Refusal of drink offers can lead } \\
\text { to exclusion from social events. }\end{array}$ & $\begin{array}{l}\text { - Representatives of sample } \\
\text { - Personal alcohol use not } \\
\text { reported by participants }\end{array}$ \\
\hline \multicolumn{5}{|l|}{ Quantitative } \\
\hline Shore et al. (1983) & $645 \mathrm{M} / \mathrm{F}$ & $\begin{array}{l}\text { Participants mailed surveys and } \\
\text { asked to respond to six vignettes } \\
\text { describing offers of alcohol }\end{array}$ & $\begin{array}{l}\text { - Positive correlation between social } \\
\text { ease in situations and resistance to } \\
\text { overt offers of alcohol (ROA). } \\
\text { - Year in school, but not age, is } \\
\text { positively correlated with ROA. } \\
\text { - Personal alcohol use and ROA } \\
\text { inversely correlated. }\end{array}$ & $\begin{array}{l}\text { - Seniors overrepresented } \\
\text { in sample } \\
\text { - External validity of } \\
\text { responses to vignettes } \\
\text { - } 65 \% \text { response rate }\end{array}$ \\
\hline Klein (1992) & $297 \mathrm{M}, 218 \mathrm{~F}$ & $\begin{array}{l}\text { Surveyed students using a } \\
\text { stratified sampling procedure } \\
\text { to ensure equal representation } \\
\text { of residence type. }\end{array}$ & $\begin{array}{l}\text { - Year in school positively correlated } \\
\text { with approval of saying "no" to an } \\
\text { offered drink. } \\
\text { - Women more likely than men to } \\
\text { refuse an alcoholic drink. } \\
\text { - Men residing in fraternities least } \\
\text { likely to refuse an offered drink. }\end{array}$ & $\begin{array}{l}\text { - } 44 \% \text { response rate } \\
\text { - Use of single item to } \\
\text { assess direct peer influence } \\
\text { - Sample size precluded } \\
\text { gender comparisons } \\
\text { - Frequency of accepting } \\
\text { drink offers not evaluated }\end{array}$ \\
\hline Wood et al. (2001) & $136 \mathrm{M}, 263 \mathrm{~F}$ & $\begin{array}{l}\text { Offers of alcohol use assessed } \\
\text { by single survey item: "In the } \\
\text { past year, how many times have } \\
\text { you been offered an } \\
\text { alcoholic drink?" }\end{array}$ & $\begin{array}{l}\text { - Positive association found between } \\
\text { alcohol offers and alcohol use and } \\
\text { alcohol-related problems } \\
\text { - Relationship between alcohol offers } \\
\text { and alcohol use was not mediated } \\
\text { by alcohol-related expectancies }\end{array}$ & \\
\hline
\end{tabular}

$\mathrm{F}=$ female $; \mathrm{M}=$ male $\mathrm{M} / \mathrm{F}=$ gender of participants not provided 
phenomenon are relatively rare. Although the limited research makes any inferences preliminary, two themes emerge. First, active offers to drink may be more common than quantitative research has indicated: a qualitative study suggests that not drinking at college social functions is regarded as an unusual behavior that will elicit several offers to drink (Rabow \& Duncan-Schill, 1994). Thus, nondrinking students at parties are repeatedly offered drinks and often exposed to teasing from friends and report feelings of inferiority. Second, students that are more socially secure can resist overt peer offerings of alcohol by peers. Specifically, social ease (Shore, Rivers, \& Berman, 1983), socializing with an established group of peers, and year in school (Klein, 1992) were all positively correlated with refusing an offered drink, suggesting that maturity and/or social confidence may make students more resilient to peer offers of alcohol. Conversely, new students attempting to develop friendships with peers and adapt to college life may be more likely to accept offers of alcohol. Although the studies did not address directly the issue of social skills (or drink refusal skills), the findings imply that ability to resist overt offers of alcohol may be, in part, a skills-based behavior. The finding that women refused offered drinks more than men suggests that expectations related to gender role continue to influence susceptibility to peer influence.

\subsubsection{Limitations: direct peer influence}

The limited number of studies on this topic makes it difficult to determine which are replicable findings. Retrospective surveys are subject to self-report bias. Specifically, students may have inaccurately represented the nature of their responses to active peer influences. In addition, assessing the frequency of being offered a drink does not reveal whether the offer was accepted. Similarly, the vignette method may not have provided an accurate assessment of the student's susceptibility to accepting drink offers in the real world. The external validity of findings based on responses to written scenarios also remains to be demonstrated. Thus, the development of more immediate and context-dependent means of assessing direct peer influence would be worthwhile.

\subsection{Indirect peer influence: modeling}

The modeling of peer drinking is a potent indirect influence on personal alcohol use because peers are highly salient and available models in college (Lau, Quadrel, \& Hartman, 1990). Although the terms modeling, imitation, and observational learning have often been used interchangeably (White et al., 1991), modeling is defined here as the temporary and concurrent imitation of another's behavior. Laboratory study of modeling became popular in the late 1970 s and early 1980 s, after field observations of college drinkers found that alcohol consumption was associated with drinking group size (Cutler \& Storm, 1975) and gender composition (Rosenbluth, Nathan, \& Lawson, 1978). The degree of experimental control in modeling research made it possible to isolate the characteristics of drinking companions that facilitated alcohol use. Although modeling research has been performed with adults (see Quigley \& Collins, 1999), the 13 studies summarized in Table 2 involve college student participants and share a common format. First, the participant is paired with another student who is actually a confederate (or model) trained by the researchers to consume alcohol at a 
Modeling literature

\begin{tabular}{|c|c|c|c|c|}
\hline Authors & Subjects & Design & Results & Limitations \\
\hline $\begin{array}{l}\text { Caudill and } \\
\text { Marlatt (1975) }\end{array}$ & $\begin{array}{l}48 \mathrm{M} \text {, } \\
\text { heavy } \\
\text { drinkers }\end{array}$ & $\begin{array}{l}\text { Students participated in } \\
\text { a wine-tasting task }(15 \mathrm{~min}) \\
\text { with a male confederate. } \\
3(\mathrm{HDM} / \mathrm{LDM} / \mathrm{NM}) \times \\
2(\text { warm/cold confederate }) \\
\text { factorial design. }\end{array}$ & $\begin{array}{l}\text { - Participants exposed to HDM consumed } \\
\text { significantly more alcohol than those } \\
\text { exposed to LDM. } \\
\text { - There were no differences in alcohol } \\
\text { consumption between participants in the } \\
\text { LDM and NDM conditions. } \\
\text { - Interaction with model (warm or cold) } \\
\text { for } 7 \text { min prior to wine-tasting task did } \\
\text { not influence the modeling effect. } \\
\text { - Half of participants were aware of an } \\
\text { effect of the confederate on their alcohol } \\
\text { use (e.g., "social pressure" or competition). }\end{array}$ & $\begin{array}{l}\text { - External validity of task } \\
\text { - Brevity of social } \\
\text { interaction before } \\
\text { drinking task }(7 \mathrm{~min}) \\
\text { - Male participants only }\end{array}$ \\
\hline $\begin{array}{l}\text { Garlington and } \\
\text { Dericco (1977) }\end{array}$ & $\begin{array}{l}3 \mathrm{M} \text {, } \\
\text { moderate } \\
\text { drinkers }\end{array}$ & $\begin{array}{l}\text { Students drank beer in a } \\
\text { simulated tavern setting } \\
(1 \mathrm{~h}) \text { with a male } \\
\text { confederate. } \\
\text { ABACA reversal design, } \\
\text { where: } A=\text { same drinking } \\
\text { rate as participant; } B=1 / 3 \\
\text { higher; and } C=1 / 3 \text { lower. }\end{array}$ & $\begin{array}{l}\text { - Participants modeled confederate's } \\
\text { drinking rate during the session. }\end{array}$ & $\begin{array}{l}\text { - Participants openly } \\
\text { observed by researchers } \\
\text { - Small number of } \\
\text { participants } \\
\text { - Male participants only }\end{array}$ \\
\hline $\begin{array}{l}\text { Dericco and } \\
\text { Garlington (1977) }\end{array}$ & $\begin{array}{l}3 \mathrm{M} \text {, } \\
\text { moderate } \\
\text { drinkers }\end{array}$ & $\begin{array}{l}\text { Students drank beer in a } \\
\text { simulated tavern setting } \\
(1 \mathrm{~h}) \text { with a male } \\
\text { confederate. ABACADA } \\
\text { reversal design, where: } A= \\
\text { same drinking rate as } \\
\text { participant; } B=1 / 3 \text { higher; }\end{array}$ & $\begin{array}{l}\text { - Participant modeled confederate's } \\
\text { drinking rate during the session, } \\
\text { even after being told that the } \\
\text { confederate was trying to influence } \\
\text { his alcohol use. }\end{array}$ & $\begin{array}{l}\text { - Participants openly } \\
\text { observed by researchers } \\
\text { - Small number of } \\
\text { participants } \\
\text { - Male participants only }\end{array}$ \\
\hline
\end{tabular}

$\begin{array}{cll}\text { Hendricks et al. } & 36 \mathrm{M}, & \begin{array}{l}\text { influence drinking. } \\ \text { (1978) }\end{array} \\ & \text { heavy and } & \text { wine-tasting and (b) art-rating } \\ & \text { light drinkers } & \text { tasks (30 min) with a }\end{array}$

\section{- Participants exposed to HDM} consumed more alcohol than those with LDM, regardless of social condition.
- External validity of task

- No light/heavy

drinker comparisons 
male confederate.

$2(\mathrm{HDM} / \mathrm{LDM}) \times 3$ (social

condition: co-action:

simultaneous drinking;

audience facilitation

reversed task order with

confederate tasting wine first;

imitation: confederate

tastes wine first and then

leaves) factorial design.

Dericco (1978)

$2 \mathrm{M}, 2 \mathrm{~F}$

Students drank beer in a simulated

tavern setting $(1 \mathrm{~h})$ with three

confederates (either two males or

females or vice versa). All four

participants run simultaneously.

Two confederates drank either fast

or slow, with the third confederate

drinking at the opposite pace.

Single-subject repeated-

measures design.

Cooper et al. (1979) $32 \mathrm{M}, 32 \mathrm{~F}, \quad$ Students participated in a moderate wine-tasting task (15 $\mathrm{min})$. or heavy $2(\mathrm{HDM} / \mathrm{NM}) \times$

drinkers 2 (sex of participant $) \times$

2 (sex of confederate)

factorial design.

\section{Lied and Marlatt}

(1979)

$32 \mathrm{M}, 32 \mathrm{~F}$, Students participated in a light and wine-tasting task (15 $\mathrm{min})$

heavy with a male confederate.

drinkers
- Observing the model drink

heavily before the task did not influence personal alcohol use.

- Consumption was influenced by the behavior of the pair of confederates; the drinking rate of the single confederate was ignored.

Therefore, when multiple models are present, the individual models the drinking rate of the majority.

- The gender of the participant or the confederate had no

influence on drinking rate.

- Participants that performed taste test at same time with HDM

consumed more alcohol than participants that performed taste test with NM, regardless of sex of participant or confederate.

- Same-sex dyads consumed more alcohol than mixed-sex dyads, with male/male dyads displaying greatest consumption of alcohol use. - Participants paired with HDM drank more than those with LDM.

- Heavy social drinkers consumed more alcohol, regardless of their gender or drinking level of model.
- Male participants only

- Two participants replaced due to awareness of confederate influence

- Participants openly observed by researchers

- Small number of participants

- External validity of task

- No LDM comparison

group.

- Brevity of drinking task

- Two participants

removed due to awareness of experiment

- External validity of task

- Competition could

explain similarities in alcohol consumption

(continued on next page) 
Table 2 (continued)

\begin{tabular}{|c|c|c|c|c|}
\hline Authors & Subjects & Design & Results & Limitations \\
\hline & & $\begin{array}{l}\text { participant drinking history) } \\
\text { factorial design. }\end{array}$ & $\begin{array}{l}\text { - No significant gender differences in } \\
\text { alcohol consumption. }\end{array}$ & $\begin{array}{l}\text { - Brevity and novelty } \\
\text { of drinking situation } \\
\text { - Novelty of the task } \\
\text { may have suppressed } \\
\text { gender differences } \\
\text { - Two participants } \\
\text { suspected model was } \\
\text { a confederate. }\end{array}$ \\
\hline $\begin{array}{l}\text { Dericco and } \\
\text { Niemann (1980) }\end{array}$ & $\begin{array}{l}2 \mathrm{M}, 1 \mathrm{~F} \text {, } \\
\text { moderate } \\
\text { drinkers }\end{array}$ & $\begin{array}{l}\text { Students drank beer in a } \\
\text { simulated tavern setting } \\
(1 \mathrm{~h}) \text { with two confederates } \\
\text { of the same gender. ABACA } \\
\text { reversal design, where: } \\
\mathrm{A}=\text { same drinking rate } \\
\text { as participant; } \mathrm{B}=\text { one } \\
\text { confederate drank } 1 / 3 \text { faster, } \\
\text { the other } 1 / 3 \text { slower; and } \mathrm{C}= \\
\text { confederates' drinking rate. }\end{array}$ & $\begin{array}{l}\text { - Consumption of participant closely } \\
\text { matched that of fast-drinking confederate; } \\
\text { slow rates of confederate drinking had no } \\
\text { effect on participant consumption. } \\
\text { - No gender differences demonstrated: } \\
\text { the female matched drinking rate as } \\
\text { closely as the men. } \\
\text { - Drinking rate was not the result of the } \\
\text { participant's emulation of a particular } \\
\text { confederate, as the faster-drinking } \\
\text { confederate was modeled at all times. }\end{array}$ & $\begin{array}{l}\text { - Participants openly } \\
\text { observed by researchers } \\
\text { - Small number of } \\
\text { participants }\end{array}$ \\
\hline $\begin{array}{l}\text { Collins et al. } \\
\text { (1985, Study I) }\end{array}$ & $\begin{array}{l}52 \mathrm{M} \text {, } \\
\text { moderate } \\
\text { and heavy } \\
\text { drinkers }\end{array}$ & $\begin{array}{l}\text { Students drank in bar-like } \\
\text { setting }(30 \text { min) with male } \\
\text { confederates. } 2 \text { (HDM/LDM) } \times \\
2 \text { (sociable/unsociable model }) \\
\text { factorial design. } \\
\text { Three to four dyads run } \\
\text { at same time }\end{array}$ & $\begin{array}{l}\text { - The sociable confederate maintained a } \\
\text { conversation with the participant about } \\
\text { sports and college life during the drinking } \\
\text { session. The unsociable confederate did not } \\
\text { elicit any conversion, and answered any } \\
\text { questions with short phrases or single words. } \\
\text { - Participants unaware of modeling } \\
\text { influences of confederate. }\end{array}$ & $\begin{array}{l}\text { - Brevity of drinking } \\
\text { situation } \\
\text { - No moderate/heavy } \\
\text { drinker comparisons } \\
\text { - Possible presence of } \\
\text { group effects } \\
\text { - Male participants only }\end{array}$ \\
\hline
\end{tabular}


Collins et al.

$54 \mathrm{M}$,

(1985, Study II) moderate and heavy drinkers

Chipperfield and
Vogel-Sprott
(1988)

$50 \mathrm{M}$,

heavy drinkers

Students participated in cocktail task-rating task (15 min). $2(\mathrm{HDM} / \mathrm{LDM}) \times$ 2 (participant's family history of drinking problems,$$
\mathrm{FH}+/ \mathrm{FH}-\text { ) }
$$

Corcoran (1995)

$60 \mathrm{M}, 73 \mathrm{~F}, \quad$ Confederate modeled moderate and choosing an alcoholic or

heavy nonalcoholic beverage.
- Modeling occurred in the sociable model condition; however, participants paired with unsociable LDM and HDM drank as much as participants paired with sociable HDM.

- Participants modeled rate of LDM and HDM.

- Social status of model failed to influence the modeling of alcohol consumption.

- Participants unaware of any confederate effects on drinking.

- $\mathrm{FH}+$ participants modeled the alcohol consumption of HDM and LDM to a greater extent than the $\mathrm{FH}-$ participants.

- Participants had no awareness of confederate effects on alcohol use.

- Participants modeled confederate's beverage selection.

- Participant drinker status (moderate or heavy) or gender of the confederate did nor influence modeling of confederate beverage choice.
- Status based on

demographics, not

drinking-related similarities

- Possible presence of

group effects

- Male participants only

- Brevity of drinking

situation

- External validity of task

- Male participants only

- External validity of task

- Light drinkers not

included in study. 
certain pace (heavy or light). A modeling effect is demonstrated if the participant's alcohol consumption matches that of the confederate. Overall, the modeling research indicates that participants exposed to heavy-drinking models consume more than students exposed to lightdrinking models or no models at all. As with adults (Quigley \& Collins, 1999), both confederate and participant characteristics appear to influence this effect in college students.

Three characteristics of the model influence participant consumption. First, the participant matches the concurrent drinking of the confederate: previous observation of a model does not influence the participant's subsequent drinking (Cooper, Waterhouse, \& Sobell, 1979; Hendricks, Sobell, \& Cooper, 1978). Therefore, during a single session, a confederate can increase or decrease the participant's rate of consumption (Dericco \& Garlington, 1977; Garlington \& Dericco, 1977) or facilitate the selection of an alcoholic beverage (Corcoran, 1995). Second, composition of the group of confederates influences participant alcohol use. When two confederates drink at different rates, participants model the fast rate of drinking (Dericco \& Niemann, 1980). When in a larger group, the rate exhibited by the majority of confederates is modeled (Dericco, 1978). Third, the sociability of the confederate (warm or cold) during the session appears to influence modeling. Heavy drinking is evident in participants paired with a heavy-drinking sociable model, but not with a light-drinking sociable model. However, when models are unsociable, both heavy- and light-drinking models are associated with heavy drinking (Collins, Parks, \& Marlatt, 1985, Study I). There are two ways the unsociable model may influence alcohol use. On the one hand, a participant may drink heavily in reaction to the adverse environment, and this motivation may overwhelm the modeling influence of the confederate. This supports the coping role of alcohol in social learning theory (see Maisto et al., 1999). On the other hand, the heavy drinking in the presence of an unsociable model may also have been the result of boredom. When with a light-drinking confederate that did not talk, there may have been little else for participants to do but drink.

One characteristic of the model that did not seem to moderate the modeling effect was the social status of the model (Collins et al., 1985, Study II). That is, participants were paired with either a high-status (a 30-year-old medical resident with an affluent background and "impeccable" dress), typical-status (a 21-year-old junior with a middle-class background, a good vocabulary, and casual dress) and a low-status (a 21-year-old laborer from a disadvantaged background, a limited vocabulary, and "crude" manner and dress) model all exhibited similar drinking patterns.

Three participant characteristics appear to influence modeling. First, regardless of the modeling condition or gender of the participant, heavy drinkers consume significantly more alcohol than light drinkers (Lied \& Marlatt, 1979). Second, participants with a family history of drinking problems match the model's drinking rate to a greater degree than those without such a history (Chipperfield \& Vogel-Sprott, 1988). This increased response to confederate drinking may be the result of observing inconsistent drinking models within the family context, making it necessary to observe others in the immediate drinking context for cues on appropriate drinking rates. Third, the gender of the participant appears to influence modeling. Females consistently drink less than males, regardless of the confederate drinking rate or prior drinking history (Cooper et al., 1979; Dericco \& Niemann, 1980; Lied \& Marlatt, 1979). 
While biological differences may account for this discrepancy (e.g., Li, Beard, Orr, Kwo, Ramchandani, 1998), competitive drinking may also facilitate the heavier drinking by males. In one study that compared same- and mixed-sex dyads, the drinking in male same-sex dyads was most extreme-although female/female dyads consumed the next highest amount (Cooper et al., 1979). Therefore, males may be especially susceptible to regarding confederate drinking as a challenge.

The participant's level of awareness of the confederate's influence does not appear to affect modeling. Instead, participants model confederate drinking whether they are aware (Caudill \& Marlatt, 1975) or unaware (Collins et al., 1985) of any possible social influences. In fact, modeling occurs even after the participant is told that their drinking companion is a confederate, and that the purpose of the research is to evaluate "whether your rate of drinking is influenced by [the confederate's] rate of drinking” (Dericco \& Garlington, 1977, p. 136).

\subsubsection{Limitations: modeling}

The literature suggests that drinking companions exert considerable influence on an individual's alcohol use. However, external validity of modeling research is limited by several factors. First, less than half of the studies included female participants. It is not known whether the warmth or status of the confederate, or a positive family history of drinking problems, would influence women's consumption differently. Second, the length of the drinking tasks was not comparable to those encountered in college. Field studies of college drinking indicate that the typical duration of a drinking episode was 2 hours (Cutler \& Storm, 1975): use of a comparable time period would enhance the generalizability of these laboratory studies. Such extended observation periods could also capture time-related changes in modeling occurring within the same session (e.g., Dericco \& Garlington, 1977) and evaluate whether the modeling effect is most potent early in a drinking session (e.g., Caudill \& Marlatt, 1975). Third, experimenter intrusion into the drinking environment posed a problem. Even in bar-like settings (e.g., Collins et al., 1985), interactions were often highly controlled (e.g., no talking with other participants allowed; participants actively observed by experimenters), resulting in a setting that was more restricted than typical college social gatherings. Finally, the novelty of the taste-rating task of wine or cocktails may have affected the drinking of participants. Since beer is overwhelmingly the beverage of choice among college students (Cutler \& Storm, 1975), its use may be more appropriate in future research. In sum, more realistic laboratory settings and field studies (e.g., Geller, Kalsher, \& Clarke, 1991) could address all of these issues. However, only two studies using the modeling paradigm have been published in the last 15 years.

\subsection{Indirect peer influence: perceived norms}

Interpreting research on perceived norms is challenging because people hold normative beliefs both about other's behaviors as well as other's beliefs and attitudes. To understand the literature on drinking norms, it is crucial to differentiate descriptive and injunctive drinking norms. Descriptive norms are the perception of other's quantity and frequency of drinking in 
discrete drinking situations (the norms of "is"). Descriptive norms have also been called "popular norms". Injunctive norms reflect the perceptions of others' approval of drinking (the norm of "ought"), and represent perceived moral rules of the peer group (also known as "prescriptive norms"). Descriptive and injunctive norms can assist the individual determine what is acceptable and unacceptable social behavior (Cialdini, Kallgren, \& Reno, 1991). Due to the size of the literature, perceived norms research is reviewed in four steps. First, a review of the survey literature reveals a relationship between perceived norms and alcohol use, and that college students frequently overestimate both types of norms on campus. Second, the influence of overestimating descriptive and injunctive norms on personal alcohol use is described. Third, a review of college interventions using norm education provides experimental evidence of the relationship between norms and personal drinking. Finally, limitations of the norm literature are discussed.

\subsubsection{Norms and drinking behavior}

The literature in Table 3 reveals that perceived normative support of others for drinking consistently predicts personal alcohol use (Clapp \& McDonnell, 2000; Liccione, 1980; Lo, 1995; Nagoshi, 1999; Nagoshi, Wood, Cote, \& Abbit, 1994; Perkins \& Wechsler, 1996; Turrisi, 1999; Werner, Walker, \& Greene, 1996; Wood, Nagoshi, \& Dennis, 1992; Wood et al., 2001), and, to a lesser extent, alcohol-related problems (Nagoshi, 1999; Wood et al., 1992, 2001). Therefore, the more the student perceives others as drinking heavily, or approving of heavy use, the higher personal consumption will be. Two trends in this literature suggest a differential influence of norms on drinking. First, people-based norms are more influential than institution-based norms (Nagoshi, 1999; Nagoshi et al., 1994; Wood et al., 1992). That is, amounts of alcohol consumption perceived to be appropriate by individuals (e.g., close friends, parents) align more closely with personal drinking behaviors than those of institutions (e.g., government officials, health authorities). Second, gender differences are evident, with men perceiving more permissive alcohol norms than females do (Adams \& Nagoshi, 1999; Lo, 1995; Nagoshi et al., 1994).

Although this literature suggests a strong link between perceived norms and alcohol use, considerable limitations make it difficult to determine precisely how norms influence drinking. In particular, the definitions of norms vary greatly in the studies, ranging from reporting whether others feel one should drink (injunctive norms; Liccione, 1980) to an estimation of peer alcohol use frequency (descriptive norms; Clapp \& McDonnell, 2000). In addition, the distinctiveness of norm assessment varies greatly. In some studies, variables representing norms combine items assessing both injunctive and descriptive norms (Perkins \& Wechsler, 1996; Turrisi, 1999), while others combine the perceived norms of a variety of groups (Adams \& Nagoshi, 1999; Nagoshi, 1999; Nagoshi et al., 1994; Wood et al., 1992). These different norm operationalizations may mask the relative influences of different reference groups.

\subsubsection{Self-other comparisons}

Self-other comparison is another approach to assessing norms; in this survey-based literature, the student reports personal use or approval of drinking. Then, the student 
Table 3

Surveys assessing influence of norms on personal alcohol use

\begin{tabular}{|c|c|c|c|}
\hline Authors & Subjects & Results & Limitations \\
\hline $\begin{array}{r}\text { Liccione } \\
(1980)\end{array}$ & $\begin{array}{l}32 \mathrm{M}, 72 \mathrm{~F} \text {, } \\
\text { Interviewed college } \\
\text { students under the } \\
\text { age of } 21\end{array}$ & $\begin{array}{l}\text { - Normative support for drinking defined as whether four target groups } \\
\text { (adults, parents, other students approximately the same age, and friends) } \\
\text { "had a feeling" about whether the participant should drink or not. } \\
\text { - Only normative support of drinking by friends was correlated with Q/F of } \\
\text { personal alcohol use. This suggests that peers and } \\
\text { friends may different influence on personal alcohol use. } \\
\text { - Only normative support of drinking by friends was correlated with Q/F of } \\
\text { personal alcohol use. This suggests that peers and } \\
\text { friends may different influence on personal alcohol use. } \\
\text { - Only normative support of drinking by friends was correlated with } \mathrm{Q} / \mathrm{F} \text { of } \\
\text { personal alcohol use. This suggests that peers and } \\
\text { friends may different influence on personal alcohol use. }\end{array}$ & $\begin{array}{l}\text { - Selection bias } \\
\text { - Vague definition } \\
\text { of approval } \\
\text { - Cross-sectional data leave di- } \\
\text { rectionality of the relationship } \\
\text { between normative influence } \\
\text { and alcohol use unclear }\end{array}$ \\
\hline $\begin{array}{l}\text { Wood et al. } \\
\text { (1992) }\end{array}$ & $\begin{array}{l}134 \mathrm{M}, 148 \mathrm{~F}, \\
\text { College student } \\
\text { drinkers }\end{array}$ & $\begin{array}{l}\text { - Perceived norms were determined by participant ratings of what the } \\
\text { members of two groups would deem as an appropriate amount of alcohol to } \\
\text { consume (ranging from } 1=\text { none to } 5=\text { more than one drink per day). The } \\
\text { two types of norms were: people-based (parents, siblings, spouse/ } \\
\text { significant other, roommate, close friends, social group members, work- } \\
\text { office acquaintance) and institution-based (moral/religious authorities, } \\
\text { authorities, government officials). } \\
\text { - People-based norms positively correlated with alcohol Q/F and alcohol- } \\
\text { related problems; institution-based norms positively } \\
\text { correlated only with alcohol Q/F. } \\
\text { - People-based norms were more influential } \\
\text { than institution-based norms in predicting } \\
\text { personal Q/F of drinking. }\end{array}$ & $\begin{array}{l}\text { - Approval of individual targets } \\
\text { not reported } \\
\text { - Cross-sectional data } \\
\text { - Considerable amount of miss- } \\
\text { ing data for norms measure }\end{array}$ \\
\hline $\begin{array}{l}\text { Nagoshi } \\
\text { et al. } \\
\text { (1994) }\end{array}$ & $\begin{array}{l}151 \mathrm{M} / \mathrm{F} \\
\text { College student } \\
\text { drinkers }\end{array}$ & $\begin{array}{l}\text { - Norms assessed as in Wood et al. (1992). } \\
\text { - Men reported higher people-based norms for alcohol use than women. } \\
\text { - Drinking game participation was significantly negatively correlated with } \\
\text { institution-based norms of alcohol use, suggesting that drinking game } \\
\text { participation may be a way of rebelling against institutional norms. } \\
\text { - People-based norms predicted the frequency of getting drunk. }\end{array}$ & $\begin{array}{l}\text { - Approval of individual targets } \\
\text { not reported } \\
\text { - Cross-sectional data }\end{array}$ \\
\hline
\end{tabular}


Table 3 (continued)



Werner

et al.

(1996)
Baseline: 452

$\mathrm{M} / \mathrm{F}$; 32-month follow-up: $184 \mathrm{M} / \mathrm{F}$ gender, age, Greek membership, religion).

- Participants asked to describe best friend as: (a) nondrinker, (b) light,

(c) moderate, or (d) heavy social or problem drinker.

- Friend's drinking significantly positively correlated with personal Q/F of drinking at both baseline and follow-up.

- Friend's drinking was significant predictor of alcohol use at follow-up.

Perception of friend's drinking remained consistent over 3 years and was
- $59 \%$ attrition rate

- Nonrespondents at follow-up reported higher $\mathrm{Q} / \mathrm{F}$ of alcohol use and more alcohol-related problems 


\begin{tabular}{|c|c|c|c|}
\hline $\begin{array}{l}\text { Adams and } \\
\text { Nagoshi } \\
\text { (1999) }\end{array}$ & $\begin{array}{l}70 \mathrm{M}, 121 \mathrm{~F}, 4 \mathrm{M} / \mathrm{F} \text {, } \\
\text { Current and former } \\
\text { college student } \\
\text { drinkers. Two } \\
\text { assessments: early } \\
\text { September } \\
\text { and mid- to } \\
\text { late November }\end{array}$ & $\begin{array}{l}\text { - Norms assessed were same as in Nagoshi et al. (1992). } \\
\text { - Test-retest correlations calculated for people-based (.62) } \\
\text { and institution-based (.34) norms. } \\
\text { - Younger students perceived lower social and institutional norms } \\
\text { than older students, suggesting that exposure to heavy drinking } \\
\text { in college may raise the level of perceived norms over time. } \\
\text { - Social and institutional norms did not predict changes in (a) alcohol } \\
\text { use frequency or (b) alcohol-related problems. } \\
\text { - Compared to females, males perceived more permissive social and } \\
\text { institutional norms. }\end{array}$ & $\begin{array}{l}\text { - Used age instead of class } \\
\text { standing to classify first-year } \\
\text { and older students } \\
\text { - Time frame of alcohol-related } \\
\text { problems measure differed at } \\
\text { baseline (lifetime) and follow- } \\
\text { up (past month) } \\
\text { - Approval of individual targets } \\
\text { not reported } \\
\text { - Cross-sectional data }\end{array}$ \\
\hline $\begin{array}{l}\text { Nagoshi } \\
\text { (1999) }\end{array}$ & $\begin{array}{l}71 \mathrm{M}, 95 \mathrm{~F}, \\
\text { College student } \\
\text { drinkers }\end{array}$ & $\begin{array}{l}\text { - Norms assessed were same as in Nagoshi et al. (1992). } \\
\text { - People-based norms positively correlated with personal Q/F, alcohol } \\
\text { related problems, binge drinking, and frequency of getting drunk. } \\
\text { - People-based norms to be a significant predictor of personal Q/F. }\end{array}$ & $\begin{array}{l}\text { - Approval of individual targets } \\
\text { not reported } \\
\text { - Cross-sectional data }\end{array}$ \\
\hline $\begin{array}{l}\text { Turrisi } \\
\text { (1999) }\end{array}$ & $\begin{array}{l}113 \mathrm{M}, 137 \mathrm{~F}, \\
\text { College students } \\
\text { assessed } 1 \\
\text { week apart }\end{array}$ & $\begin{array}{l}\text { - Normative influence assessed by creating single variable evaluating } \\
\text { participant's level of agreement with: (a) my friends will think I am strange } \\
\text { if I don't drink; (b) it probably can't be bad that everyone in my age group } \\
\text { is drinking; and (c) most of my friends drink. } \\
\text { - Norms not a significant predictor of binge drinking when entered into } \\
\text { model after (a) cognitions towards drinking and (b) attitudes } \\
\text { towards drinking. }\end{array}$ & $\begin{array}{l}\text { - Descriptive and injunctive } \\
\text { items combined in variable re- } \\
\text { presenting normative influence } \\
\text { - Cross-sectional data }\end{array}$ \\
\hline $\begin{array}{l}\text { Clapp and } \\
\text { McDo- } \\
\text { nell } \\
(2000)\end{array}$ & $\begin{array}{l}181 \mathrm{M}, 228 \mathrm{~F}, \\
\text { College students }\end{array}$ & $\begin{array}{l}\text { - Norms defined as the perception of the amount of alcohol normally } \\
\text { consumed by their peers }(0=\text { never; } 6=\text { almost daily). } \\
\text { - Perceived peer norms were a significant predictor of (a) binge drinking } \\
\text { and (b) frequency of alcohol use in the past } 30 \text { days. } \\
\text { - Perceived norms approximated actual self-reported use on campus, } \\
\text { suggesting that students may accurately perceive the alcohol use occurring } \\
\text { around them. }\end{array}$ & $\begin{array}{l}\text { - Older undergraduate sample } \\
\text { (mean age }=24 \text { ) } \\
\text { - No perceived norms of drink- } \\
\text { ing quantity recorded } \\
\text { - Measurement of norms on } \\
\text { different scales }\end{array}$ \\
\hline $\begin{array}{l}\text { Wood et al. } \\
\qquad(2001)\end{array}$ & $136 \mathrm{M}, 263 \mathrm{~F}$ & $\begin{array}{l}\text { - Perceived norms were associated indirectly with alcohol-related } \\
\text { problems through alcohol use. } \\
\text { - No evidence that alcohol-related expectancies mediate the relationship } \\
\text { between perceived norms and alcohol use or alcohol-related problems }\end{array}$ & $\begin{array}{l}\text { - Sample size precluded gender } \\
\text { comparisons } \\
\text { - Self-other comparisons not } \\
\text { reported }\end{array}$ \\
\hline
\end{tabular}

significantly correlated with concurrent and future risk for problem drinking.

- Norms assessed were same as in Nagoshi et al. (1992).

college may raise the level of perceived norms over time.

- Compared to females, males perceived more permissive social and

related problems, binge drinking, and frequency of getting drunk.

- People-based norms to be a significant predictor of personal $\mathrm{Q} / \mathrm{F}$.

model after (a) cognitions towards drinking and (b) attitudes

consumed by their peers $(0=$ never; $6=$ almost daily $)$.

and (b) frequency of alcohol use in the past 30 days.

- Perceived norms approximated actual self-reported use on campus, ing that students may accurately perceive the alcohol use occurring

problems through alcohol use

No evidence that alcohol-related expectanc

$\mathrm{F}=$ female; $\mathrm{M}=$ male $\mathrm{M} / \mathrm{F}=$ gender of participants not provided; $\mathrm{Q} / \mathrm{F}=$ quantity/frequency. 
Surveys assessing self-other normative comparisons

\begin{tabular}{|c|c|c|}
\hline Authors & Subjects & Results \\
\hline \multicolumn{3}{|c|}{ Descriptive norms } \\
\hline $\begin{array}{l}\text { Banks and } \\
\text { Smith (1980) }\end{array}$ & $\begin{array}{l}24 \mathrm{M}, 66 \mathrm{~F} \text {, } \\
\text { light and heavy } \\
\text { drinkers }\end{array}$ & $\begin{array}{l}\text { - Light drinkers perceived friends as drinking more than themselves; heavy } \\
\text { drinkers perceive friends as drinking the same amount as themselves. } \\
\text { - Only seven students reported drinking more than their friends. }\end{array}$ \\
\hline $\begin{array}{l}\text { Mooney and } \\
\text { Corcoran } \\
(1991)\end{array}$ & $\begin{array}{l}90 \mathrm{M}, 93 \mathrm{~F}, \\
\text { drinkers }\end{array}$ & $\begin{array}{l}\text { - Males and females reported that their best friend did not drink } \\
\text { significantly more per occasion than themselves. } \\
\text { - Males and females reported that their best friend drank significantly more } \\
\text { frequently than themselves. } \\
\text { - For both males and females, personal use was predicted by perceived } \\
\text { quantity of best friend's drinking. }\end{array}$ \\
\hline $\begin{array}{l}\text { Baer et al. } \\
\quad(1991, \\
\text { Study I) }\end{array}$ & $\begin{array}{l}65 \mathrm{M}, 66 \mathrm{~F} \text {, } \\
\text { high-risk freshman } \\
\text { drinkers (based on } \\
\text { drinking during } \\
\text { senior year in } \\
\text { high school) }\end{array}$ & $\begin{array}{l}\text { - Participants perceived close friends as consuming more drinks per } \\
\text { occasion. } \\
\text { - Close friends perceived to drink more alcohol than self, but the same } \\
\text { number of times per week. The typical student was perceived to drink less } \\
\text { alcohol less frequently than self. } \\
\text { - Personal alcohol use significantly correlated perceived drinking of close } \\
\text { friends, but not the perception of typical student drinking. } \\
\text { - Typical student on campus perceived to drink less than self. } \\
\text { - No gender differences in norm perception. }\end{array}$ \\
\hline $\begin{array}{l}\text { Baer et al. } \\
\text { (1991, } \\
\text { Study II) }\end{array}$ & $\begin{array}{l}147 \mathrm{M}, 133 \mathrm{~F} \text {, } \\
\text { residents of } \\
\text { dormitories and } \\
\text { Greek houses }\end{array}$ & $\begin{array}{l}\text { - Elevated descriptive norms were found for (a) close friends and (b) } \\
\text { members of residence. } \\
\text { - Dormitory and sorority residents perceive typical student to drink more } \\
\text { than themselves; fraternity residents perceive typical students to drink less. } \\
\text { - All students perceived typical student as consuming } 16 \text { drinks per week; } \\
\text { actual norm is } 8-10 \text { drinks per week. } \\
\text { - Perceptions of close friend's drinking, not that of typical student, are } \\
\text { most correlated with personal consumption. }\end{array}$ \\
\hline $\begin{array}{l}\text { Baer and } \\
\text { Carney } \\
(1993)\end{array}$ & $\begin{array}{l}96 \mathrm{M}, 156 \mathrm{~F}, \\
\text { Greek residents, } \\
\text { light and heavy } \\
\text { drinkers }\end{array}$ & $\begin{array}{l}\text { - Self-reported drinking ( } 14.3 \text { drinks per week) was estimated to be lower } \\
\text { than drinking of best friend (15.4) and of typical student }(21.1) \text {. } \\
\text { - Only males rated the drinking of (a) their best friend and (b) a fellow } \\
\text { member of fraternity house to be significantly higher than personal alcohol } \\
\text { consumption. }\end{array}$ \\
\hline
\end{tabular}

Limitations

- Small number of males did not allow for gender analyses

- Correlational nature of data prohibits evaluation of influence of elevated norms as a result of socialization or selection

- Potential selection bias: student recruited by newspaper ads, flyers, and class announcements

- No low-risk comparison group

- Self-selection within Greek house residents

- Only 4 of 48 Greek houses participated in survey

- Potential selection bias: 4 of 48 Greek houses participated in survey 
Baer (1994)

$56 \mathrm{M}, 70 \mathrm{~F}$, high-risk freshmen screened before entry into college, then assessed in mid-autumn and late spring.

\section{Larimer}

et al. (1997)

$157 \mathrm{M}, 219 \mathrm{~F}$,

Greek members

in houses with different drinking reputations: high (HI), medium (MED), and low (LO)

Thombs

et al. (1997)

Perkins et al. (1999) ondary analysis of CORE institute data collected in 1994 and 1996 at 100 schools
- Drinking level in residence positively correlated with the student's perceived norm of the alcohol use of the typical student.

- All students perceived (a) fraternities, (b) sororities, and (c) dormitory residents as drinking heavily (in that order).

- Perceived norms did not change across the transition to college or during freshmen year.

- Participants reported consuming 10 drinks on two occasions per week, yet perceived fraternity members as consuming eight or more drinks nearly every day as well as (a) dormitory residents and (b) sorority members as consuming seven to eight drinks three to four times a week.

- Men in HI houses perceive themselves as drinking the same amount as fellow house members, but Greek members and typical student drank less.

- Men in MED houses perceived themselves as drinking the same as fellow house members, less than other Greek students, and more than typical students.

- Men in LO houses perceived themselves as drinking the same as other house members and the typical student, but less than other Greek members. - Regardless of house reputation, women perceived fellow house members and other Greek students as drinking more than themselves. In regard to the perception of the drinking of typical students, MED and LO members perceived themselves as drinking less, while HI members viewed typical students as drinking the same as themselves.

- Participants perceived their close friends as drinking significantly more than themselves; "most students" were perceived as drinking significantly more than self or close friends.

- Perception of close friend's drinking habits, but not "most students," significantly related to personal use.

- Perceived alcohol use of typical students was consistently inflated when compared to the campus average of self-reported drinking.

- Misperception of the average student drinking every week was most prominent on campuses where abstinence or light drinking was the selfreported average.

- At schools where weekly drinking was the self-reported average, less than $3.5 \%$ of the students provided deflated estimates, $75 \%$ provided
- Gender analyses not performed due to uneven distribution of men and women in three residential settings (off-campus, dorm, Greek housing)

- Possible deselection of highrisk drinkers, since participants were all volunteers

- Modest participation rate within houses $(42-78 \%)$

- Analyses with MED and LO houses had low power. Differences in norm perception of residents and nonresidents of houses not addressed.

- 10 of 48 Greek houses participated

- Possible overrepresentation of heavy drinkers in sample: $55.3 \%$ averaged $5+$ drinks per occasion, while the national average of this level of consumption is $40-42 \%$ (Johnson et al., 1996).

- Only one target used for norm estimation (average student) 


\begin{tabular}{ll}
\hline Authors & Subjects \\
\hline & \\
Carter and & $299 \mathrm{M}$, \\
$\begin{array}{l}\text { Kahnweiler } \\
(2000)\end{array}$ & fraternity members
\end{tabular}

Results

Limitations

accurate estimates, and $22 \%$ provided inflated estimates of the drinking

norm.

- Post hoc multiple comparisons of the five targets (non-Greek men, typical student, self, close friend, Greek, men) revealed that fraternity members perceived themselves as drinking more than non-Greek men and the typical student on campus, the same as their closest friend, and less than Greek men.

- Close friend's drinking on Thursday, Friday, and Saturday was perceived to be higher than personal use on the same days.

Thombs (2000)

$169 \mathrm{M}, 128 \mathrm{~F}$, student athletes

- Assessed perceived Q/F of alcohol use of (a) typical teammate and (b) typical student on campus.

- Paired sample $t$ test revealed that athletes perceived typical teammates and typical student on campus as consuming more alcohol than themselves (in that order).

- Perceived drinking norms of (a) and (b) modestly differentiated abstainers from drinkers; however, age of drinking onset was a much more robust discriminator.

Wechsler and

Kuo (2000)

Injunctive norms

Perkins and

Berkowitz

(1986a)
$14,138 \mathrm{M} / \mathrm{F}$, students completed the College Alcohol Survey

$1116 \mathrm{M} / \mathrm{F}$
- Students asked to report the proportion of students at their school that were binge drinkers, and then compared self-reported binge drinking rates to these estimates.

- $47 \%$ of students underestimate binge drinking; $29 \%$ overestimate it.

- Binge drinkers are more likely to be accurate in their perceptions than non-binge drinkers.

- More overestimation at low-binge-drinking schools, and more underestimation at high-binge-drinking schools.

- Students who overestimate binge drinking on campus more likely to be binge drinkers themselves.

- Students perceived other students on campus as having a more liberal attitude towards alcohol use than themselves.

- Drinking is associated with the degree of consistency between personal and perceived approval of alcohol use: heavy drinking and social function attendance associated with liberal personal and perceived attitudes towards
- One fraternity excluded from participation due to violation of campus alcohol policies

- $44 \%$ participation rate

of fraternity members

- Greek membership of

close friend not recorded

- Generalizability of findings

- Greek membership of

athletes not assessed

- Arbitrary definition of accurate norm perception (within $10 \%$ of actual campus rate)

- Target may have lacked salience (e.g., might have included friends, typical students, etc.)

- $64 \%$ response rate 
Perkins and

Berkowitz

(1986b)

Prentice and Miller (1993,

Study I)

Prentice and

Miller (1993,

Study II)

Prentice and

Miller (1993,

Study III)

Baer (1994)
Resident

advisors (RA): 39

M, 34 F; Students:

$796 \mathrm{M}, 611 \mathrm{~F}$

$63 \mathrm{M}, 69 \mathrm{~F}$

63.

$97 \mathrm{M}, 145 \mathrm{~F}$

25 M, 25 F, freshmen assessed at beginning and end of first semester

\section{$56 \mathrm{M}, 70 \mathrm{~F}$,} freshmen screened before entry into college, mid-autumn, and late spring $176 \mathrm{M}, 178 \mathrm{~F}$ Greek members; $521 \mathrm{M}, 922 \mathrm{~F}$ nonmembers drinking. Perceiving others to have more liberal attitudes associated with lower levels of alcohol use.

Both RA and students perceived other students on campus as having more liberal attitudes towards drinking (e.g., "an occasional drunk is O.K.").

- Students, especially women, perceived average students on campus to be significantly more comfortable with alcohol use than themselves.

- Students incorrectly perceive the average student to be more approving of alcohol that themselves; the actual level of approval of alcohol use on campus is significantly lower.

- Students perceived friends and average students as being more comfortable with alcohol use than themselves.

- The order of the questions or the salience of target is not solely responsible for elevated norm perception.

- Women's injunctive norms of the typical student more elevated than men's.

- Men's personal and perceived approval of alcohol use converged over the course of the semester; this effect was not evident in women.

- Over the semester, men's alcohol use and perceived comfort of others with alcohol use improved as predictors of personal comfort with alcohol use.

- Greek members rated injunctive norms as more extreme than nonmembers; however, these elevated drinking norms were evident before entry into college.

- Students perceive friends as becoming more disapproving of alcohol use as the year progresses - except if one resides in a fraternity or sorority house.

- Evaluated approval of a close friend for three personal drinking levels: (a) 1-2 drinks/day; (b) 3-4 drinks/day; and (c) 5+ drinks/day.

- Compared to Greek members, non-Greek student's close friends were more likely to disapprove of (b) and (c); Compared to fraternity members, sorority member's close friends were more likely to disapprove of (c)

- For Greek members, close friend's disapproval of (b) and (c) predicted personal alcohol use; for non-Greeks, close friends disapproval of (a), (b), and (c) predicted personal alcohol use.
- Questions not

counterbalanced

- Small convenience sample

- Gender analyses not performed due to uneven distribution in three residential settings

- Selection bias: high-risk

drinkers volunteered

- Representatives of sample: mean age was

21.8 years, and the majority $(91.4 \%)$ lived off-campus.

- Personal approval of drinking levels not assessed 
estimates the alcohol use or approval of drinking of others (known as targets: e.g., best friend, typical student). Then, these estimates are compared to surveys of personal alcohol use in order to detect a discrepancy between perceived and actual alcohol use and approval of drinking on campus.

The surveys of descriptive norms in Table 4 indicate that, regardless of the target, students commonly overestimate the quantity and frequency of alcohol consumption of those around them. Specifically, students frequently perceive close friends (Baer \& Carney, 1993; Baer, Stacy, \& Larimer, 1991; Banks \& Smith, 1980; Larimer, Iruine, Kilmer, \& Marlatt, 1997; Mooney \& Corcoran, 1991; Thombs, Wolcott, \& Farkash, 1997) and the typical college student (Baer, 1994; Baer \& Carney, 1993; Canter \& Kahnweiler, 2000; Perkins, Meilman, Leichliter, Cashin, \& Presley, 1999; Thombs, 2000; Thombs et al., 1997) as drinking more than themselves. In fact, it is extremely rare for personal use to be reported as higher than all other targets; only fraternity members exhibit this trend (Canter \& Kahnweiler, 2000; Larimer et al., 2000). Indeed, these individuals are likely to be the heaviest drinkers on campus (Wechsler et al., 2000). In sum, although the perceived hierarchy of drinkers may change, students consistently rate some other target as drinking more than themselves.

Elevated descriptive norms are especially prevalent in the Greek system, with members consistently reporting high estimates of drinking for friends, fellow residents, and typical students (Baer \& Carney, 1993; Baer et al., 1991, Study II; Canter \& Kahnweiler, 2000; Larimer et al., 1997). Such overestimation of alcohol use appears to be mutual, as non-Greek students consistently perceive Greek residents to be the heaviest drinkers on campus (Baer \& Carney, 1993; Baer et al., 1991, Study II). Two factors may perpetuate such misperceptions of descriptive norms in the Greek system: house reputation and precollege perceptions.

Regarding house reputation, students tend to classify fraternities and sororities by the amount of alcohol the typical member consumes (Larimer et al., 1997). Such house drinking reputations facilitate an elevated perception of descriptive norms: individuals in high-drinking houses are perceived by both members and nonmembers as drinking more than those in lower-drinking houses. Although these elevated norms have some basis in fact, it is interesting to note that even members of houses with heavy-drinking reputations perceive others in the house as drinking more than themselves (Larimer et al., 1997). This suggests that social reputation can play a prominent role in the misperception of other's drinking, and elevated descriptive norms may be a source of pride and tradition.

The student may also perceive the Greek system as a place to drink heavily prior to arrival on campus (Baer, 1994), possibly a result of the cultural portrayal of college as a place to drink heavily (Thombs, 1999). These norms then appear to remain stable over the course of freshman year (Baer, 1994). As a result, even before being exposed to the Greek system, new students may view its members as drinking more than is actually the case. For some, elevated norms may increase the attractiveness of the Greek system (e.g., Borsari \& Carey, 1999).

Similar trends are evident in the injunctive norm literature presented in Table 4. First, compared to their personal attitudes, students consistently estimate that typical students are more comfortable with (Prentice \& Miller, 1993) and more approving of (Perkins \& Berkowitz 1986a, 1986b) alcohol use. Close friends are also perceived to approve of excessive drinking more than the student (Alva, 1998; Baer, 1994; Prentice \& Miller, 
1993, Study II). Second, misperceptions of injunctive norms are present for both members and nonmembers of the Greek system. Specifically, members of the Greek system report nonmembers as being more tolerant of alcohol use; at the same time, nonmembers perceive members as being the most tolerant of alcohol use on campus (Baer, 1994). Such elevated injunctive norms can perpetuate the belief that peers are more comfortable with excessive drinking than oneself.

In sum, both elevated descriptive and injunctive norms make excessive alcohol use seem common and acceptable. Although it is likely that these estimates contain some basis in fact (e.g., the Greek system being perceived as a place to drink heavily), evidence suggests that they are frequently inflated. In a survey of over 48,000 students at 100 schools, self-reported frequency of drinking was consistently lower than the estimated drinking of the typical student, regardless of the school's size, location, and average self-reported drinking on campus (Perkins et al., 1999). This perception of alcohol use as common and acceptable is likely to influence behavior as "subjective perceptions, be they accurate or inaccurate, must be taken as important in their own right, because people act on their perceptions of their world in addition to acting within a real world" (Perkins \& Wechsler, 1996, p. 962).

\subsubsection{Influence of norms on drinking behavior}

The survey literature suggests that perceived norms appear to influence personal alcohol use in a two-step process. In the first step, personal alcohol use and/or attitudes are compared to perceived descriptive and injunctive norms (e.g., of a best friend or the typical student) and a discrepancy is perceived to exist. This discrepancy has often been explained by the theories of pluralistic ignorance and attribution theory. Pluralistic ignorance occurs when "individuals assume that their own private attitudes are more conservative than are those of other students, even though their public behavior is identical" (Schroeder \& Prentice, 1998, p. 2152). This assumption results in two errors in perception: (a) individuals misperceive the attitudes of the target group; and (b) individuals perceive themselves as being deviant from the norm (Miller $\&$ Prentice, 1994). Attribution theory, on the other hand, proposes that students have limited knowledge about the actual behaviors and attitudes of other students. As the student observes others drinking heavily, it is assumed that such excessive use is typical, resulting in elevated norms. In this way, observed drinking behaviors are inferred to be common. The less the student associates with the target group, the more likely such misperceptions will occur because attitudes and behaviors are more likely to be generalized (Perkins, 1997). In sum, both theories propose that students tend to overestimate other students' alcohol use and approval of drinking.

In the second step, exaggerated norms influence personal alcohol use. Students act in ways representative of the perceived group norm, not their personal view. Thus, a student will match the drinking they perceive other students doing (descriptive norm) and approving of (injunctive norm). The influence of such norms can be complex and reciprocal. For example, students perceiving others as drinking heavily may drink in a similar manner. This behavior is then observed by other students, perpetuating the perception of heavy drinking as the norm. Students may then feel pressured to conform to these elevated descriptive and injunctive norms, perpetuating heavy alcohol use (Perkins, 1997). These elevated norms also make it 
less likely that individuals will view their own drinking as problematic, reducing the impetus for change.

The association between both types of perceived norms and personal alcohol use has been explained in different ways. With regard to descriptive norms, the perceived consumption of close friends is more highly associated with a student's drinking than that of typical student. This finding may result from greater knowledge of the drinking of close friends (Baer et al., 1991; Thombs et al., 1997), or self-selection into a peer group with comparable drinking habits (Borsari \& Carey, 1999). In addition, students may use elevated descriptive and injunctive norms to justify excessive personal alcohol use (Perkins \& Wechsler, 1996). With regard to injunctive norms, one potential motivation to conform is a fear of negative evaluation. Students who want to avoid negative evaluation from peers may match their behaviors with perceived approval from others (Schroeder \& Prentice, 1998). Violating these norms can make one appear different, which is especially undesirable in social situations. Research supports this hypothesis: abstainers receive significantly less social acceptance than moderate drinkers (Trice \& Beyer, 1977). In addition, fear of negative evaluation is a significant predictor of choosing an alcoholic beverage (vs. a nonalcoholic one) only when the participant believes that fellow students will be made aware of his or her choice (Corcoran \& Segrist, 1993). As a result, it may be less socially risky to conform to descriptive and injunctive norms in an effort to be perceived as relaxed and at ease with drinking.

In sum, the literature indicates that being surrounded by peers that are perceived to both participate in and approve of excessive drinking may be associated with increased levels of personal use. However, this does not imply that all students exposed to such norms will experience alcohol problems or dependence. Instead, a variety of psychological (e.g., religiosity) and social (e.g., social support) moderators can affect the influence of peer norms on alcohol use (Perkins, 1997).

\subsubsection{Interventions using norms}

Surveys provide only correlational evidence of the association between norms and drinking behavior. In contrast, intervention research assessing changes in alcohol use following descriptive or injunctive norm education provides experimental evidence of this relationship. The recent increase in the attention paid to social norms (Keeling, 2000) has resulted in numerous studies evaluating whether norm education can change both the student's perception of norms as well as alcohol consumption.

Interventions using descriptive and injunctive norm education are detailed in Table 5. Norm education has been provided in the form of individualized normative feedback (Agostinelli, Brown, \& Miller, 1995; Borsari \& Carey, 2000; Walters, 2000; Walters, Bennett, \& Miller, 2000), group sessions (Barnett, Far, Mauss, \& Miller, 1996; Schroeder \& Prentice, 1998; Steffian, 1999), mailed greeting cards (Werch et al., 2000), and campus-wide campaigns (Haines \& Spear, 1996). All six of the interventions that attempted to change descriptive norms reported significant reductions in norm perception (Barnett et al., 1996; Borsari \& Carey, 2000; Haines \& Spear, 1996; Steffian, 1999; Walters, 2000; Walters et al., 2000). Therefore, descriptive norm education, administered in a variety of formats, appears to be an effective method of changing student perceptions of other's drinking. 
Table 5

Interventions using description or injunctive norm education

\begin{tabular}{|c|c|c|c|}
\hline Authors & Design & Results & Limitations \\
\hline \multicolumn{4}{|c|}{ Descriptive norms } \\
\hline $\begin{array}{l}\text { Agostinelli } \\
\text { et al. (1995) }\end{array}$ & $\begin{array}{l}12 \mathrm{M}, 11 \mathrm{~F} \text {, heavy } \\
\text { drinkers. Random as- } \\
\text { signment to: Group I: } \\
\text { mailed feedback; } \\
\text { Group 2: no treatment } \\
\text { control. Two assess- } \\
\text { ments: baseline and } \\
6 \text { weeks }\end{array}$ & $\begin{array}{l}\text { - Group } 1 \text { received mailed feedback immediately after assessment, } \\
\text { including comparisons of personal alcohol use to actual US norms. } \\
\text { - ANOVAs revealed that at } 6 \text {-week follow-up, there was a significant } \\
\text { decrease in alcohol consumption of Group 1; Group } 2 \text { reported no } \\
\text { drinking decreases. }\end{array}$ & $\begin{array}{l}\text { - Selection bias: } 26 / 64 \text { heavy } \\
\text { drinkers agreed to participate } \\
\text { - Perceived drinking of others } \\
\text { not assessed } \\
\text { - Small sample size at follow-up } \\
\text { due to attrition } \\
\text { - Low power to detect between- } \\
\text { group effects }\end{array}$ \\
\hline $\begin{array}{l}\text { Barnett } \\
\text { et al. (1996) }\end{array}$ & $\begin{array}{l}1426 \mathrm{M} / \mathrm{F} \text {. Random } \\
\text { assignment to: } \\
\text { Group 1: norm educa- } \\
\text { tion (NE); Group 2: } \\
\text { values clarification } \\
\text { (VC); Group 3: NE/VC } \\
\text { combined; Group 4: } \\
\text { control. Three assess- } \\
\text { ments: baseline, during } \\
\text { groups (2-3 weeks } \\
\text { postbaseline), and } \\
4 \text { weeks }\end{array}$ & $\begin{array}{l}\text { - ANOVAs using change scores revealed that only the NE session } \\
\text { facilitated decreases in perceived descriptive norms of (a) close friends } \\
\text { and (b) the typical student. } \\
\text { - Drinking reductions in the NE and NE/VC groups accompanied by } \\
\text { changes in several perceived norms, not just one. } \\
\text { - At } 4 \text {-week follow-up, NE group reported decreases in drinking of } \\
\text { close friends, residence members, typical students, and family } \\
\text { members. }\end{array}$ & $\begin{array}{l}\text { - High attrition by } 4 \text { weeks } \\
(78 \%) \\
\cdot \quad \text { Difficulty maintaining treat- } \\
\text { ment integrity within groups }\end{array}$ \\
\hline $\begin{array}{l}\text { Haines and } \\
\text { Spear (1996) }\end{array}$ & $\begin{array}{l}\text { Five surveys com- } \\
\text { pleted: Time 1: } 291 \mathrm{M} \text {, } \\
\text { 353 F; Time 2: } 360 \mathrm{M} \text {, } \\
\text { 419 F; Time 3: } 313 \mathrm{M} \text {, } \\
\text { 403 F; Time 4: } 343 \mathrm{M}, \\
\text { 449 F; Time 5: } 361 \mathrm{M} \text {, } \\
\text { 453 F }\end{array}$ & $\begin{array}{l}\text { - A traditional alcohol education was implemented after Time } 1 \text {; a } \\
\text { media campaign on accurate descriptive norms initiated after Time } 2 \text {. } \\
\text { - From Time } 1 \text { to Time } 5 \text {, chi-square analyses revealed significant } \\
\text { decreases reported in perception of binge drinking ( } 6+\text { drinks on one } \\
\text { occasion) as the norm }(69.7-51.2 \%) \text { and personal binge drinking } \\
\text { 'when you party' ( } 43-34.2 \%) \text {. } \\
\text { - NE appeared to be more effective than the traditional approach in } \\
\text { lowering perceived and personal reports of binge drinking. }\end{array}$ & $\begin{array}{l}\text { - Historical effects cannot be } \\
\text { ruled out because there were no } \\
\text { control group comparisons } \\
\text { - Perceived norms of other } \\
\text { targets not assessed }\end{array}$ \\
\hline Steffian (1999) & $\begin{array}{l}71 \mathrm{M} \text {. Group 1: norma- } \\
\text { tive feedback; Group 2: } \\
\text { alcohol education film }\end{array}$ & $\begin{array}{l}\text { - Group } 1 \text { exhibited significant reductions in the perception of average } \\
\text { student (a) drinks per week and (b) number of binge drinking episodes } \\
\text { per week. }\end{array}$ & $\begin{array}{l}\text { - Recall period of } 2 \text { weeks led to } \\
\text { overlap of baseline and 1-week } \\
\text { assessments }\end{array}$ \\
\hline
\end{tabular}

(continued on next page) 


\begin{tabular}{|c|c|c|c|}
\hline Authors & Design & Results & Limitations \\
\hline \multirow{3}{*}{$\begin{array}{l}\text { Borsari and } \\
\text { Carey (2000) }\end{array}$} & $\begin{array}{l}(30 \mathrm{~min}) . \text { Three assess- } \\
\text { ments: immediately } \\
\text { prior to the intervention } \\
\text { and at } 1 \text { and } 4 \text { weeks }\end{array}$ & $\begin{array}{l}\text { - There were no significant reductions in the quantity and frequency of } \\
\text { personal alcohol use in either group at follow-ups. }\end{array}$ & $\begin{array}{l}\text { - Nonrandom group assignment } \\
\text { - Baseline group differences not } \\
\text { addressed in analyses } \\
\text { - All-male participants }\end{array}$ \\
\hline & $\begin{array}{l}26 \mathrm{M}, 34 \mathrm{~F} \text {, heavy } \\
\text { drinkers. Group 1: brief } \\
\text { motivational interven- } \\
\text { tion (BMI); Group 2: } \\
\text { no treatment control. } \\
\text { Two assessments: base- } \\
\text { line and } 6 \text { weeks }\end{array}$ & $\begin{array}{l}\text { - At baseline and follow-up, both BMI and control group participants } \\
\text { perceived typical students and friends to drink more than themselves. }\end{array}$ & - Selection bias \\
\hline & & $\begin{array}{l}\text { At 6-week follow-up, descriptive norms of typical student mediated } \\
\text { group membership and personal alcohol use. } \\
\text { - In BMI group, significant reductions in descriptive norms of friends } \\
\text { and the typical student found at follow-up. }\end{array}$ & $\begin{array}{l}\text { - Lack of active comparison } \\
\text { group }\end{array}$ \\
\hline Walters $(2000)$ & $\begin{array}{l}46 \mathrm{M} / \mathrm{F} \text {, moderate to } \\
\text { heavy drinkers. Rando- } \\
\text { mized to three groups: } \\
\text { Group 1: 2-hour } \\
\text { classroom alcohol } \\
\text { information session } \\
\text { and personalized } \\
\text { discussion of alcohol } \\
\text { use; Group } 2: \text { mailed }\end{array}$ & $\begin{array}{l}\text { - Mailed feedback included comparisons of perceived and actual } \\
\text { norms of drinking. }\end{array}$ & - Attrition of $26 \%(n=13)$ \\
\hline
\end{tabular}


feedback only;

Group 3: no treatment control. Assessed at

Walters

et al. $(2000)$

$40 \mathrm{M} / \mathrm{F}$, moderate to

heavy drinkers.

Randomized to three groups: Group 1:

2-hour information session and personalized mailed feedback;

Group 2: personalized mailed feedback only;

Group 3: no treatment control. Assessed at baseline and at 6 weeks

Injunctive norms

Barnett

et al. (1996)

1426 M/F. Randomized assignment to: Group 1: NE; Group 2: VC; Group 3: NE/VC combined; Group 4: control. Three assessments: baseline, during groups (2-3 weeks, postbaseline), and 4 weeks

Schroeder and

Prentice

(1998)

$79 \mathrm{M}, 64 \mathrm{~F}$, freshmen. Random assignment to: Two 1-hour group dis- baseline and 6 weeks

- Mailed feedback group exhibited a reduction of 6.6 fewer drinks per week, followed by the no treatment control (2.8) and the classroom feedback (0.35).

- Mailed feedback and personalized discussion included comparisons of perceived and actual norms of drinking.

- Participants in Group 2 exhibited largest decrease in drinking (13.8 drinks per week), followed by Group 1 (0.4) and Group $3(0.36)$.

- Dormitory residents receiving the NE reported greatest decreases in perceived approval of alcohol use by close friends, peers, and the typical student.

- Greek members receiving NE displayed a reduction in perceived approval of close friends, fellow house residents, and the typical student.

- Students receiving the NE/VC reported significant reductions in the perceived approval of fellow dormitory members.

- In all groups, decreases in perceived approval of drinking were associated with changes in alcohol use.

- The PO group reported drinking significantly fewer drinks per week cussions: peer-oriented (PO) and individually oriented (IO). Two
(3.10) than IO (5.05) at follow-up.

- Men's discrepancy between personal and perceived comfort with drinking decreased over time; women's discrepancy between personal and perceived comfort of others did not change between baseline and follow-up.
- Small group size

- Short follow-up period

- Small group size

- Short follow-up period.

- $75 \%$ attrition rate

- Low treatment integrity

- Norm changes from baseline to

4-week follow-up not reported

- Only two questions evaluated alcohol use

- Data collection stopped after newspaper published article about the study, resulting in large dropout rate $(n=309)$

(continued on next page) 


\begin{tabular}{|c|c|c|c|}
\hline \multirow[t]{2}{*}{ Authors } & Design & Results & Limitations \\
\hline & $\begin{array}{l}\text { assessments: baseline } \\
\text { and } 4-6 \text { months }\end{array}$ & $\begin{array}{l}\text { - At follow-up, there were no group differences in the perception of the } \\
\text { typical student's comfort with alcohol use. }\end{array}$ & $\begin{array}{l}\text { - Close to } 20 \% \text { of both groups } \\
\text { were abstainers } \\
\cdot \text { Perceived comfort of close } \\
\text { friends not assessed. Institution } \\
\text { bias. }\end{array}$ \\
\hline
\end{tabular}

$\mathrm{F}=$ female $; \mathrm{M}=$ male $\mathrm{M} / \mathrm{F}=$ gender of participants not provided. 
It is unclear whether similar changes occur with injunctive norms; only two interventions have been published. One large-scale study found that 4 weeks after receiving norm education, both dormitory residents and Greek members reported decreases in the perceived approval of alcohol use of close friends and the typical student (Barnett et al., 1996). In contrast, Schroeder and Prentice (1998) did not detect any group differences in norm perception at a longer (4-6 months) follow-up. However, a gender difference did emerge over the course of the study: men exhibited a greater reduction in the discrepancy between personal and perceived approval of drinking than women. This reduction was primarily the result of a decrease in the perceived approval of the average student. An untested hypothesis proposes that gender differences in the use of alcohol in socialization may have accounted for this change. Specifically, men are much more involved in the drinking environment than women; as a result, men have to reconcile their personal and perceived norms (Schroeder \& Prentice, 1998).

Self-reported alcohol use decreased following most of these interventions. Specifically, six of the eight studies reported significant reductions following descriptive norm education (Agostinelli et al., 1995; Barnett et al., 1996; Borsari \& Carey, 2000; Haines \& Spear, 1996; Walters, 2000; Walters et al., 2000). In addition, the two injunctive norm interventions reported reductions in alcohol use (Barnett et al., 1996; Schroeder \& Prentice, 1998). While norm education appears causally linked to changes in drinking behaviors, the exact mechanisms have yet to be determined. For example, it is unclear whether changes in norm perception are solely responsible for the observed decreases in alcohol use. Although one study demonstrated a mediating effect of changes in drinking norms (Borsari \& Carey, 2000), this finding has yet to be replicated. Other factors may also contribute to these drinking reductions. For instance, challenging the notion that alcohol use is widely endorsed, thus reducing the pressure to drink in order to conform, may reduce a fear of negative evaluation (Schroeder \& Prentice, 1998). An improved understanding of the mechanisms related to observed drinking reductions is vital to the development and implementation of more precise and effective interventions.

\subsubsection{Limitations: descriptive and injunctive norms}

Four methodological limitations characterize the descriptive and injunctive norm literature. First, 18 different targets have been used in norm research, ranging from "your best friend" (Baer \& Carney, 1993) to "an average student" (Perkins et al., 1999; Steffian, 1999). It is possible that each of these targets differ in their degree of salience and specificity to the participant. Previous research found that the drinking of one's best friend did not appear to be overestimated, suggesting that students may use different strategies to estimate individual and group behaviors (Baer \& Carney, 1993). As a result, some student-generated estimates may be more factually based (best friend) than others (average student), influencing the accuracy and replicability of the discrepancy derived from self-other estimates. Second, only two studies evaluated possible order effects in norm estimation. One study found no effect of rating personal use before or after other targets (Baer et al., 1991), while later research indicated that the order of the ratings did influence norm estimates (Baer \& Carney, 1993; Prentice \& Miller, 1993). Such trends may influence the interpretation of the results. Third, 
the underrepresentation of minorities is a consistent limitation in the norm literature (as in almost all studies in this review). Such limited minority representation results in an inadequate understanding of ethnic differences in norm perception, as well as limiting the external validity of the research (Sue, 2000). Fourth, the norm interventions often contained other components. For example, descriptive norm education was usually accompanied by other techniques, such as discussion of drinking problems and suggestions to reduce alcohol use (Agostinelli et al., 1995; Barnett et al., 1996; Borsari \& Carey, 2000; Walters, 2000; Walters et al., 2000). These, and not the provision of accurate norms, may have facilitated the observed reductions in alcohol use. Thus, in future research, care should be taken to differentiate the effective components in norm education programs that are associated with drinking reductions.

\section{Implications for future research}

Recent research has demonstrated the unique contributions of different types of peer influence on college student drinking. Wood and colleagues (2001) evaluated direct (offers to drink) and indirect (social modeling and descriptive norms) social influences on alcohol use and problems in college students. Offers to drink and social modeling were strongly associated with both use and problems, while perceived norms were associated only with alcohol use. In addition, alcohol expectancies were found to mediate the relationship between social modeling and alcohol use and problems. While these findings demonstrate the utility of evaluating different aspects of peer influence, some methodological improvements would benefit this emerging area of research.

Direct peer influence on alcohol use is worthy of more research, given the qualitative reports of the prevalence of overt offers of alcohol use (Rabow \& Duncan-Schill, 1994). However, the few studies that evaluate one's susceptibility to drink offers have relied on retrospective surveys (Klein, 1992; Wood et al., 2001) or the use of written role-play vignettes (Shore et al., 1983). Quantitative diaries (e.g., Nezlek, 1993) or Ecological Momentary Assessment (EMA; Collins et al., 1998) may be more sensitive and externally valid methods of assessment. Because their contents are unlimited and not fixed to exact targets, these self-monitoring methods allow students to record: (a) who is pressuring them to drink; (b) the context; (c) the type(s) of drink offered; and (d) their responses to discrete offers of alcohol. If completed shortly after the drinking event takes place, information can be obtained regarding the likelihood and outcomes of active offers to drink in different college drinking contexts. Ethnographic studies with adults (Prus, 1983) suggest the importance of direct peer influence in the context of buying rounds in bars, as slower drinkers have to drink faster to keep up. In addition, self-monitoring methods may elucidate gender differences in the functional significance of responses to active offers of alcohol. For example, men's increased likelihood of accepting offered drinks may be related to the possible competitive nature of drinking among males (Lied \& Marlatt, 1979). Men, more so than women, may see drink offers as an opportunity to show others that they can hold their liquor. If so, certain aspects of the situation may predict succumbing to direct peer influence (e.g., gender of the 
peer offering alcohol). Furthermore, self-monitoring methods could also improve our understanding of the relationship between risky alcohol use and drinking games (e.g., Nagoshi et al., 1994), where commands to drink are common. In sum, more information is needed regarding the interrelations between context, gender, and specific forms of direct peer influence, and event-based outcomes may inform prevention efforts.

With regard to modeling, the robustness of the modeling effect lies in perplexing contrast to the relative lack of research conducted on this topic in recent years. In light of the fact that many of the previous findings emerged in the 1970s and 1980s, it would be productive to replicate the more promising effects with the current generation of college students, many of who had not been born at the time of the landmark studies. In particular, gender effects should be evaluated with regard to model characteristics (e.g., warmth, status, familiarity to the participant) as well as participant characteristics (e.g., family history of alcoholism, fear of negative evaluation, social conformity). Similar research on the effects of ethnicity would also be valuable, as this topic has been completely overlooked by previous research. In the modeling research, several procedural steps could be taken to increase external validity of research findings. For example, the observation of modeling in friendship groups would help to determine the parameters of modeling in naturally occurring groups. In reality, it is rare for college students to drink in groups that do not include at least one person known to the student (Orcutt, 1991). Observing peer drinking could be accomplished by recruiting the participant's peers to participate in a drinking session (in the field or the laboratory). In addition, the length of the drinking session should also be expanded past the typical 15-min period. In this way, conversation and interactions among peers would better approximate a typical social interaction. Naive peers in the group would be observed and monitored to evaluate both individual and group modeling effects. For example, if changes in group drinking rates could be monitored over time, certain members of peer group may emerge as more influential than others (e.g., setting the drinking pace). Conversely, modeling may be a function of the number of individuals exhibiting a certain rate (the majority's drinking pace is modeled by the slower drinkers in the group, or vice versa). In sum, the use of such peer groups and longer observation sessions would permit the greater approximation of the influences of modeling in the actual college drinking environment.

In research on perceived norms, a need has emerged to standardize the terms used in the literature. As mentioned earlier, peer norms have been operationalized in a variety of ways, making the definitions of norms unclear. Thus, it would be beneficial to establish a precise terminology differentiating between descriptive and injunctive norms, as well as establishing a standardized approach or set of approaches to evaluate norms. Specifically, self-other comparisons should be derived from questions in which the stem is the same and only the target differs (e.g., self, best friend, average student); comparisons of responses to questions worded differently may result in inaccurate or misleading results.

Efforts to standardize the techniques in the field would avoid misunderstandings that can be counterproductive. An illustration of this involves a recent survey of over 14,000 students at over 100 schools which revealed that only $29 \%$ of students overestimated the proportion of binge drinkers on campus (Wechsler \& Kuo, 2000). This was the first study not to detect a general tendency to overestimate other's drinking, leading the authors to contend, "students 
have a greater understanding of the extent of binge drinking than they are given credit for" (Wechsler \& Kuo, 2000, p. 63). Given the emerging popularity of norm-based programs (Keeling, 2000), this finding was received with concern and confusion. However, closer analysis of the methodology revealed two problems (DeJong, 2000). First, students were not provided with a clear definition of binge drinking when making their estimates of other's drinking. This precludes accurate comparisons between actual and estimated rates, because the estimation rate may be based on a different, more idiosyncratic definition of binge drinking. Second, the researchers used a somewhat arbitrary definition of accuracy of perceived binge drinking: the student was deemed to accurately perceive other's drinking if within $\pm 10 \%$ of actual campus binge drinking rate (based on self-reported use). Therefore, this procedure obscured the detection of under- or overestimations of binge drinking on campus that may be reliable but less than $10 \%$. This incident illustrates the need for researchers to adopt common approaches to assess norms.

Clarification of the definitions and methods for assessing perceived norms would improve our understanding of how norm perception can be changed, and the subsequent influence of norm-based interventions on drinking behavior. For example, one study has examined the influence of (a) normative and (b) self-focusing information on the evaluation of personal alcohol use (Nye, Agostinelli, \& Smith, 1999). Results suggest that providing normative information about the drinking of typical students of the same gender resulted in a reappraisal of personal alcohol use. In addition, preliminary evidence suggests that a reduction in perceived descriptive norms does mediate drinking behavior change (Borsari \& Carey, 2000). Such findings should encourage further research on the mechanisms underlying intervention effects.

\section{Conclusion}

In sum, ample evidence demonstrates that interpersonal processes strongly influence college student drinking. The peer environment contributes to high-risk alcohol use by way of direct influences, modeling, and perceived norms. Each of these sources of influence has been studied in relative isolation, using different research methods (e.g., qualitative, experimental, survey, and interventions research). This critical review has highlighted limitations of extant research, and offered suggestions for furthering our understanding of each set of influences. In light of the lack of significant change on indices of risky drinking over the last several years (Wechsler et al., 2000), the prominent role that peers play in the drinking behaviors of college students deserves greater attention. Recent support for the utility of considering unique types of peer influence on college drinking (Wood et al., 2001) only highlights the need for improved research on variables in the peer environment that influence personal alcohol consumption, alone and in combination. It is possible that many of the factors that influence college students may generalize to young adults in general, or to groups of individuals that encounter drinking practices and norms unlike anything encountered before (e.g., immigrants). 


\section{Acknowledgments}

This work was supported in part by NIAAA grants F31-AA05571 to Brian Borsari and R01 AA12518 to Kate B. Carey.

\section{References}

Adams, C., \& Nagoshi, C. T. (1999). Changes over one semester in drinking game playing and alcohol use and problems in a college sample. Substance Abuse, 20, 97-106.

Agostinelli, G., Brown, J. M., \& Miller, W. R. (1995). Effects of normative feedback on consumption among heavy drinking college students. Journal of Drug Education, 25, 31-40.

Alva, S. A. (1998). Self-reported alcohol use of college fraternity and sorority members. Journal of College Student Development, 39, 3-10.

Baer, J. S. (1994). Effects of college residence on perceived norms for alcohol consumption: an examination of the first year in college. Psychology of Addictive Behaviors, 8, 43-50.

Baer, J. S., \& Carney, M. S. (1993). Biases in perceptions of the consequences of alcohol use among college students. Journal of Studies on Alcohol, 54, 54-60.

Baer, J. S., Kivlahan, D. R., \& Marlatt, G. A. (1995). High-risk drinking across the transition from high school to college. Alcoholism: Clinical and Experimental Research, 19, 54-61.

Baer, J. S., Stacy, A., \& Larimer, M. (1991). Biases in perception of drinking norms among college students. Journal of Studies on Alcohol, 52, 580-586.

Banks, E., \& Smith, M. R. (1980). Attitudes and background factors related to alcohol use among college students. Psychological Reports, 46, 571-577.

Barnett, L. A., Far, J. M., Mauss, A. L., \& Miller, J. A. (1996). Changing perceptions of peer norms as a drinking reduction program for college students. Journal of Alcohol and Drug Education, 41, 39-62.

Borsari, B., \& Carey, K. B. (2000). Effects of a brief motivational intervention with college student drinkers. Journal of Consulting and Clinical Psychology, 68, 728-733.

Borsari, B. E., \& Carey, K. B. (1999). Understanding fraternity drinking: five recurring themes in the literature, 1980-1998. Journal of American College Health, 48, 30-37.

Brennan, A. F., Walfish, S., \& AuBuchon, P. (1986). Alcohol use and abuse in college students: II. Social/ environmental correlates, methodological issues, and implications for intervention. International Journal of Addictions, 21, 475-493.

Brown, B. B., Dolcini, M. M., \& Leventhal, A. (1997). Transformations in peer relationships at adolescence: implications for health-related behavior. In: J. Schulenberg, J. L. Maggs, \& K. Hurrelman (Eds.), Health risks and developmental transitions during adolescence. New York: Cambridge University Press.

Canter, C. A., \& Kahnweiler, W. M. (2000). The efficacy of the social norms approach to substance abuse prevention applied to fraternity men. Journal of American College Health, 49, 66-71.

Caudill, B. D., \& Marlatt, G. A. (1975). Modeling influences in social drinking: an experimental analogue. Journal of Consulting and Clinical Psychology, 43, 405-415.

Chipperfield, D., \& Vogel-Sprott, M. (1988). Family history of problem drinking among young male social drinkers: modeling effects on alcohol consumption. Journal of Abnormal Psychology, 97, 423-428.

Cialdini, R. B., Kallgren, C. A., \& Reno, R. R. (1991). A focus theory of normative conduct: recycling the concept of norms to reduce littering in public places. Journal of Personality and Social Psychology, 58, 305-313.

Clapp, J. D., \& McDonnell, A. L. (2000). The relationship of perceptions of alcohol promotion and peer drinking norms to alcohol problems reported by college students. Journal of College Student Development, 41, 19-26.

Collins, R. L., Morsheimer, E. T., Shiffman, S., Paty, J. A., Gnys, M., \& Papandonatos, G. D. (1998). Ecological momentary assessment in a behavioral drinking moderation training program. Experimental and Clinical Psychopharmacology, 6, 306-315. 
Collins, R. L., Parks, G. A., \& Marlatt, G. A. (1985). Social determinants of alcohol consumption: the effects of social interaction and model status on the self administration of alcohol. Journal of Consulting and Clinical Psychology, 53, 189-200.

Cooper, A. M., Waterhouse, G. J., \& Sobell, M. B. (1979). Influence of gender on drinking in a modeling situation. Journal of Studies on Alcohol, 40, 562-570.

Corcoran, K. J. (1995). Cognitive and situational factors predict alcoholic beverage selection. Addictive Behaviors, $20,525-532$.

Corcoran, K. J., \& Segrist, D. J. (1993). Personal expectancies and group influences affect alcoholic beverage selection: the interaction of personal and situational variables. Addictive Behaviors, 18, 577-582.

Csikszentmihalyi, M., \& Larson, R. (1984). Being adolescent. New York: Basic Books.

Cutler, R. E., \& Storm, T. (1975). Observational study of alcohol consumption in natural settings. Journal of Studies on Alcohol, 36, 1173-1183.

DeJong, W. (2000, October 19). Note to the field: the case of the missing misperception. Higher Education for Alcohol or Drug Prevention News Digest, 155.

Dericco, D. A. (1978). Effects of peer majority on drinking rate. Addictive Behaviors, 3, 29-34.

Dericco, D. A., \& Garlington, W. K. (1977). The effect of modeling and disclosure of experimenter's intent on drinking rate of college students. Addictive Behaviors, 2, 135-139.

Dericco, D. A., \& Niemann, J. E. (1980). In vivo effects of peer modeling on drinking rate. Journal of Applied Behavioral Analysis, 13, 149-152.

Garlington, W. K., \& Dericco, D. A. (1977). The effect of modeling on drinking rate. Journal of Applied Behavioral Analysis, 10, 207-211.

Geller, E. S., Kalsher, M. J., \& Clarke, S. W. (1991). Beer versus mixed-drink consumption at fraternity parties: a time and place for low-alcohol alternatives. Journal of Studies on Alcohol, 52, 197-204.

Greenspan, S. I. (1998, July). Resisting peer pressure: how to raise a kid who knows how to say no. Parents, 73, $103-104$.

Haines, M., \& Spear, S. F. (1996). Changing the perception of the norm: a strategy to decrease binge drinking among college students. Journal of American College Health, 45, 134-140.

Hays, R. B., \& Oxley, D. (1986). Social network development and functioning during a life transition. Journal of Personality and Social Psychology, 50, 305-313.

Hendricks, R. D., Sobell, M. B., \& Cooper, A. M. (1978). Social influences on human ethanol consumption in an analogue situation. Addictive Behaviors, 3, 253-259.

Johnson, P. B. (1989). Reactions, expectancies, and college student's drinking. Psychology Report, 65, 1245-1246.

Johnston, L. D., O'Malley, P. M., \& Bachman, J. G. (2000). Monitoring the future national survey results on drug use, 1975-1999, (vol. 2). Bethesda, MD: National Institute on Drug Abuse.

Kandel, D. B. (1985). On process of peer influences in adolescent drug use: a developmental perspective. Advances in Alcohol \& Substance Use, 4, 139-163.

Kandel, D. B., \& Andrews, K. (1987). Processes of adolescent socialization by parents and peers. International Journal of Addictions, 22, 319-342.

Keeling, R. P. (2000). Social norms research in college health. Journal of American College Health, 49, 53-56.

Klein, H. (1992). College student's attitudes toward the use of alcoholic beverages. Journal of Alcohol and Drug Education, 37, 35-52.

Larimer, M. E., Iruine, D. L., Kilmer, J. R., \& Marlatt, G. A. (1997). College drinking and the Greek System: Examining the role of perceived norms for high-risk behavior. Journal of College Student Development, 38, 587-598.

Lau, R. R., Quadrel, M. J., \& Hartman, K. A. (1990). Development and change of young adult's preventative health beliefs and behavior: influences from parents and peers. Journal of Health and Social Behavior, 31, $240-259$.

Leibsohn, J. (1994). The relationship between drug and alcohol use and peer group associations of college freshmen as they transition from high school. Journal of Drug Education, 24, 177-192.

Leonard, K. E., \& Blane, H. T. (1987). Psychological theories of drinking and alcoholism. New York: Guilford Press. 
Li, T. K., Beard, J. D., Orr, W. E., Kwo, P. Y., \& Ramchandani, V. A. (1998). Gender and ethnic differences in alcohol metabolism. Alcoholism: Clinical and Experimental Research, 22, 771-772.

Liccione, W. J. (1980). The relative influence of significant others on adolescent drinking: an exploratory study. Journal of Alcohol and Drug Education, 25, 55-62.

Lied, E. R., \& Marlatt, G. A. (1979). Modeling as a determinant of alcohol consumption: effect of subject sex and prior drinking history. Addictive Behaviors, 4, 47-54.

Lo, C. C. (1995). Gender differences in collegiate alcohol use. Journal of Drug Issues, 25, 817-836.

Lo, C. C., \& Globetti, G. (1993). A partial analysis of the campus influence on drinking behavior: students who enter college as non-drinkers. Journal of Drug Issues, 23, 715-725.

Maggs, J. L. (1997). Alcohol use and binge drinking as goal-directed action during the transition to post-secondary education. In: J. Schulenberg, J. L. Maggs, \& K. Hurrelman (Eds.), Health risks and developmental transitions during adolescence. New York: Cambridge University Press.

Maisto, S. A., Carey, K. B., \& Bradizza, C. M. (1999). Social learning theory. In: K. E. Leonard, \& H. T. Blane (Eds.), Psychological theories of drinking and alcoholism (2nd ed.). New York: Guilford Press.

Martin, C. M., \& Hoffman, M. A. (1993). Alcohol expectancies, living environment, peer influence, and gender: a model of college-student drinking. Journal of College Student Development, 34, $206-211$.

Miller, D. T., \& Prentice, D. A. (1994). Collective errors and errors about the collective. Personality and Social Psychology Bulletin, 20, 541-550.

Mooney, D. K., \& Corcoran, K. J. (1991). Personal and perceived peer alcohol expectancies: their influences on alcohol consumption. Psychology of Addictive Behaviors, 5, 85-92.

Nagoshi, C. T. (1999). Perceived control of drinking and other predictors of alcohol use and problems in a college student sample. Addiction Research, 7, 291-306.

Nagoshi, C. T., Wood, M. D., Cote, C. C., \& Abbit, S. M. (1994). College drinking game participation within the context of other predictors of other alcohol use and problems. Psychology of Addictive Behaviors, 8, 203-213.

Nezlek, J. B. (1993). The stability of social interaction. Journal of Personality and Social Psychology, 65, 930-941.

Nye, E. C., Agostinelli, G., \& Smith, J. E. (1999). Enhancing alcohol problem recognition: a self-regulation model for the effects of self-focusing and normative information. Journal of Studies on Alcohol, 60, 685-693.

Orcutt, J. D. (1991). The social integration of beers and peers: situational contingencies in drinking and Intoxication. In: D. J. Pittman, \& H. R. White (Eds.), Society, culture, and drinking re-examined society, culture, and drinking re-examined. New Brunswick: Alcohol Research Documentation.

Paul, E. L., \& Kelleher, M. (1995). Precollege concerns about losing and making friends in college. Journal of College Student Development, 36, 513-521.

Perkins, H. W. (1997). College student misperceptions of alcohol and other drug norms among peers: explaining causes, consequences and implications for prevention programs. The Higher Education Center for Alcohol and Other Drug Prevention, U.S. Department of Education.

Perkins, H. W., \& Berkowitz, A. D. (1986a). Perceiving the community norms of alcohol use among students: some research implications for campus alcohol education programming. International Journal of Addictions, 21, 961-976.

Perkins, H. W., \& Berkowitz, A. D. (1986b). Resident advisors as role models: a comparison of drinking patterns of resident advisors and their peers. Journal of College Student Personnel, 27, 146-155.

Perkins, H. W., Meilman, P. W., Leichliter, J. S., Cashin, J. R., \& Presley, C. A. (1999). Misperception of the norms for the frequency of alcohol and other drug use on college campuses. Journal of American College Health, 47, 253-258.

Perkins, H. W., \& Wechsler, H. (1996). Variation in perceived college drinking norms and its impact on alcohol abuse: a nationwide study. Journal of Drug Issues, 26, 961-974.

Prentice, D. A., \& Miller, D. T. (1993). Pluralistic ignorance and alcohol use on campus: some consequences of misperceiving the social norm. Journal of Personality and Social Psychology, 64, 243-256.

Prus, R. (1983). Drinking as activity: an interactionist percpective. Journal of Studies on Alcohol, 44, 460-475.

Quigley, B. M., \& Collins, L. (1999). The modeling of alcohol consumption: a meta-analytic review. Journal of Studies on Alcohol, 60, 90-98. 
Rabow, J., \& Duncan-Schill, M. (1994). Drinking among college students. Journal of Alcohol and Drug Education, 40, 52-64.

Rosenbluth, J., Nathan, P. E., \& Lawson, D. M. (1978). Environmental influences on drinking by college students in a college pub: behavioral observations in the natural environment. Addictive Behaviors, 3, 117-121.

Schall, M., Kemeny, A., \& Maltzman, I. (1992). Factors associated with alcohol use in university students. Journal of Studies on Alcohol, 53, 122-136.

Schulenberg, J., Bachman, J. G., O’Malley, P. M., \& Johnston, L. D. (1994). High school educational success and subsequent substance use: a panel analysis following adolescents into young adulthood. Journal of Health and Social Behavior, 35, 45-62.

Schroeder, C. M., \& Prentice, D. A. (1998). Exposing pluralistic ignorance to reduce alcohol use among college students. Journal of Applied Social Psychology, 28, 2150-2180.

Shore, E. R., Rivers, P. C., \& Berman, J. J. (1983). Resistance by college students to peer pressure to drink. Journal of Studies on Alcohol, 44, 352-361.

Smetana, J. G., \& Asquith, P. (1994). Adolescents' and parents' conceptions of parental authority and personal autonomy. Child Development, 65, 1147-1162.

Steffian, G. (1999). Correction of normative misperceptions: an alcohol abuse prevention program. Journal of Drug Education, 29, 115-138.

Straus, R., \& Bacon, S. D. (1953). Drinking in college. New Haven, CT: Yale University Press.

Sue, S. (2000). Science, ethnicity, and bias: where have we gone wrong? American Psychologist, 54, 1070-7077.

Thombs, D. L. (1999). An introduction to addictive behaviors (2nd ed.). New York: Guilford Press.

Thombs, D. L. (2000). A test of the perceived norms model to explain drinking patterns among university student athletes. Journal of American College Health, 49, 75-83.

Thombs, D. L., Wolcott, B. J., \& Farkash, L. G. E. (1997). Social context, perceived norms, and drinking behavior in young people. Journal of Substance Abuse, 9, 257-267.

Trice, H. M., \& Beyer, J. M. (1977). A sociological property of drugs. Journal of Studies on Alcohol, 38, 58-74.

Turrisi, R. (1999). Cognitive and attitudinal factors in the analysis of alternatives to binge drinking. Journal of Applied Social Psychology, 29, 1512-1535.

Walters, S. T. (2000). In praise of feedback: an effective intervention for college students who are heavy drinkers. Journal of American College Health, 48, 235-238.

Walters, S. T., Bennett, M. E., \& Miller, J. H. (2000). Reducing alcohol use among college students: a controlled trial of two brief interventions. Journal of Drug Education, 30, 361-372.

Wechsler, H., \& Kuo, M. (2000). College students define binge drinking and estimate its prevalence: results from a national study. Journal of American College Health, 49, 57-64.

Wechsler, H., Lee, J. E., Kuo, M., \& Lee, H. (1990). College binge drinking in the 1990s: a continuing problem. Journal of American College Health, 48, 199-210.

Werch, C. E., Pappas, D. M., Carlson, J. M., DiClemente, C. C., Chally, P. S., \& Sinder, J. A. (2000). Results of a social norm intervention to prevent binge drinking among first-year residential college students. Journal of American College Health, 49, 85-92.

Werner, M. J., Walker, L. S., \& Greene, J. W. (1996). Concurrent and prospective screening for problem drinking among college students. Journal of Adolescent Health, 18, 276-285.

White, H. R., Bates, M. E., \& Johnson, V. (1991). Learning to drink: familial, peer and media influences. In: D. J. Pittman, \& H. R. White (Eds.), Society, culture, and drinking re-examined. New Brunswick: Alcohol Research Documentation.

Wood, M. D., Nagoshi, C. T., \& Dennis, D. A. (1992). Alcohol norms and expectations as predictors of alcohol use and problems in a college student sample. American Journal of Drug and Alcohol Abuse, 18, 461-476.

Wood, M. D., Read, J. P., Palfai, T. P., \& Stevenson, J. F. (2001). Social influence processes and college student drinking: the mediational role of alcohol outcome expectancies. Journal of Studies on Alcohol, 62, 32-43. 